\title{
UPAYA GURU MENINGKATKAN KOSAKATA ANAK MELALUI METODE BERMAIN PERAN DI TK ALKHAIRAAT 1 PUSAT PALU
}

\author{
Nurmita $^{1)}$ Nur Asmawaty ${ }^{2)}$ Erniati ${ }^{3)}$ \\ ${ }^{1}$ Mahasiswa Program Studi PIAUD FTIK Institut Agama Islam Negeri Palu \\ ${ }^{2}$ Dosen Fakultas Tarbiyah dan Ilmu Keguruan Institut Agama Islam Negeri Palu \\ ${ }^{3}$ Dosen Fakultas Tarbiyah dan Ilmu Keguruan Institut Agama Islam Negeri Palu
}

\begin{abstract}
ABSTRAK
Penelitian ini bertujuan untuk mengetahui upaya guru meningkatkan kosakata pada anak melalui metode bermain peran khususnya di sekolah Taman Kanak-kanak. Jenis penelitian yang di gunakan dalam penelitian ini adalah kualitatif deskriptif, yaitu suatu penelitian yang mendapatkan suatu gambaran secara sistematis, aktual dan akurat mengenai fakta dan perkembangan individu apa adanya. Teknik pengumpulan data yang didapatkan melalui observasi, wawancara, dan dokumentasi. Teknik analisis data yang digunakan adalah reduksi data, penyajian data, dan verifikasi data. Sedangkan keabsahan datanya akan diperkuat dengan melakukan teknik pemeriksaan. Dari hasil penelitian yang diperoleh menunjukan bahwa upaya guru dalam meningkatkan kosakata anak melalui metode bermain peran yaitu: Guru menyiapkan rencana pembelajaran harian $(\mathrm{RPPH})$, guru memperlihatkan media gambar yang sesuai dengan tema, guru membicarakan alat-alat yang akan digunakan oleh anak untuk bermain peran, guru membagi tugas kepada anak sebelum bermain peran menurut kelompoknya agar tidak berebutan, guru mengumpulkan anak untuk diberi pengarahan, memberi aturan dalam permainana, mengabsen serta menghitung jumlah anak, guru hanya mengawasi/mendampingi anak dalam bermain. Adapunfaktor pendukung dan penghambat guru dalam meningkatkan kosakata anak mealalui meode bermain peran yaitu: Kemampuan guru dalam menerapkan metode bermain peran, sarana dan prasarana, dan faktor pengambat terdapat pada beberapa anak yang jarang hadir di sekolah sehingga anak tersebut ketinggalan mengikuti kegiatan pembelajaran bermain peran di sekolah.
\end{abstract}

Kata Kunci : Kosakata, Metode bermain peran

\section{PENDAHULUAN}

Pendidikan anak usia dini merupakan salah satu tahapan pendidikan yang dapat menentukan pertumbuhan dan perkembangan anak dimasa depannya. Karena pada usia dini perkembangan dan pertumbuhan anak berkembang sangat pesat jika selalu diisi dengan hal-hal yang positif dari kedua orangtua, guru dan lingkungan sekitamya. Aspek yang dikembangkan dalam Pendidikan Anak Usia Dini adalah aspek pengembangan perilaku dengan pembiasaan yang meliputi sosial, emosi, kemandirian, nilai-nilai moral dan agama serta pengembangan kemampuan dasar yang meliputi 
pengembangan fisik motorik, kognitif dan bahasa ${ }^{1}$. Taman Kanak-kanak sebagai lembaga pendidikan memiliki keunikan dalam pelaksanaan pembelajarannya, dimana siswa dapat mengembangkan pengalaman belajamya dari lingkungan pendidikan sehingga anak akan dapat mengembankan seluruh potensi pada dirinya. Berbagai aspek dikembangkan di Taman Kanak-kanak seperti, kognitif, fisik motorik, nilai agama, moral, sosial emosional dan seni. Dan seorang guru dapat berusaha meningkatkan seluruh potensi anak termasuk perkembangan bahasa.

Perkembangan bahasa anak sejalan dengan rasa mgm tahu serta sikap antusias yang tinggi, sehingga timbul pertanyaan-pertanyaan dari anak dengan kemampuan bahasanya. Perkembangan bahasa anak antara usia 4 dan 5 tahun, kalimat anak sudah terdiri dari empat sampai lima kata. Selain itu mereka banyak menggunakan kata kerja daripada kata benda. Perkembangan bahasa anak antara usia 5 dan 6 tahun, kalimat anak sudah terdiri dari enam sampai delapan kata. Selanjutnya pada usia 5-6 tahun menurut papalia daan park (dalam buku Andy Novan Wiyani), perkembangan bahasa adalah kalimat anak sudah terdiri dari enam sampai delapan kata, dan dapat mengucapkan lebih dari 2.600 kata dan memahami lebih dari 20. 000 kata. Mereka sudah dapat menjelaskan arti kata-kata yang sederhana, mengetahui lawan kata serta kata penghubung, dan kata depan $^{2}$. Dan bahwa pada masa prasekolah anak mempunyai kemampuan mempelajari setiap bahasa dengan lebih mudah di bandingkan usia sebelum maupun dia sudah dewasa. Menurut carey dan calark (dalam buku Hari Christana Soetjininsih), pada usia 6 tahun kosakata pembicaraanya berkisar sekitar 8000-14.000 kata. Dan rata rata mereka mempelajari 22 kata baru perhari ${ }^{3}$. Untuk meningkatkan kosakata yang dimiliki oleh anak banyak sekali metode yang dapat dilakukan oleh guru sebagai pendidik, pemilihan metode yang tepat dapat menjadi penentu keberhasilan perkembangan pada anak pada khususnya kemampuan kosakata dalam aspek bahasa. Metode tersebut sebagai acuan kegiatan yang dapat meningkatkan kosakata anak, salah satu metode yang digunakan adalah metode bermain peran.

Menurut Supriyati (dalam buku Gunarti,W dkk) bahwa metode bermain peran adalah permainan yang memerankan tokoh-tokoh atau benda sekitar anak sehingga dapat mengembangkan daya khayal (imajinasi) dan penghayatan terhadap bahan kegiatan yang dilaksanakan. Maka anak dapat menjadikan dirinya sebagai sosok yang diperankannya seolah-olah dirinya menjadi pemeran tersebut ${ }^{4}$. Kegiatan bermain peran juga memiliki manfaat yang besar terutama unutuk menunjang perkembangan bahasa anak, karena dengan bermaian peran menyediakan waktu dan ruang bagi anak untuk berinteraksi dengan orang lain, mereka saling berbicara, mengeluarkan pendapat,

${ }^{1}$ Suharsimi Arikunto, Dasar-dasar Evaluasi Pendiikan, (Jakarta: Prasetyaningsih, 2014), 1

2 Andy Novan Wiyani, Psikologi Perkembangan Anak Usia Dini Panduan Bagi Orangtuadan Pendidik Dalam Memahami Serta Mendidik Anaka Usia Dini, (Yogyakarta: penerbit gava media,2014), 106

${ }^{3}$ Hari Christiana Soetjiningsih, Psikologi Perkembangan Anak Sejak PembuahanSampai Dengan Kanak-kanak Akhir, (Depok: Prenada Media Group, 2018), 151

${ }^{4}$ Gunarti,W dkk. Metode Pengembangan Perilaku dan Kemampuan Dasar Anak UsiaDini, ( Jakarta : Universitas Terbuka, 2013), 45 
menemukan jalan tengah bagi setiap persoalan yang muncul tanpa harus merasa malu. Bahkan kemampuan keaksaraan juga berkembang misalnya anak berpura-pura menulis resep obat ketika berperan sebagai dokter atau berpura-pura menulis menu makanan ketika berperan sebagai pelayan restoran dan berpura-pura menghitung uang pada saat bermain peran sebagai kasir. Oleh karena itulah bahwa bermain peran pada anak akan diharapkan dapat mengembangkan kosakata pada anak.

Dapat disimpulkan bahwa anak usia TK belajar bahasa berawal dari sesuatu yang didengar, dilihat, dan dipraktekan berpengaruh terhadap penguasaan kosakata anak. Proses belajar bahasa anak usia TK, efektif jika dapat melibatkan seluruh indera. Khususnya indera pendengaran dan penglihatan. Kemampuan komunikasi anak sangat bergantung pada perbendaharaan kata (kosakata) yang dikuasainya. Salah satu strategi yang dapat dikembangkan adalah melalui penggunaan metode bermain peran untuk meningkatkan kosa kata pada anak ${ }^{5}$.

Adapun alasan penulis tertarik pada pembahasan meningkatkan kosakata anak, karena kemampuan komunikasi anak sangat bergantung pada perbendaharaan kosakata yang dikuasainya. Sebagaimana yang dikatakan Piaget (dalam buku Hurlock), perkembangan bahasa anak TK dapat dipakai sebagai tolok ukur kecerdasanya dikemudian hari. Pada masa itu, anak menguasai kemampuan berbicara, tetapi mereka hams lebih banyak belajar sebelum mereka mencapai kemampuan berbahasa orang dewasa. Kosakata yang diperoleh anak pada awal masuk Taman Kanak-kanak kira-kira berjumlah $3000 \mathrm{kata}^{6}$. Namun kenyataan di lapangan berdasarkan dari hasil observasi awal di TK Alkhairaat 1 Pusat Palu, masalah yang terdapat di dalam kelas masih banyak anak yang belum mampu menirukan kembali 4-5 urutan kata serta belum mampu berbicara saat berinteraksi ${ }^{7}$. Dari kondisi tersebut sudah selayaknya seorang guru TK untuk melakukan usaha perbaikan. Berdasarkan hal tersebut di atas penulis bermaksud untuk melihat bagaimana upaya guru meningkatkan kemampuan kosakata anak melalui metode bermain peran.

\section{METODE PENELITIAN}

Penelitian ini menggunakan menggunakan metode penelitian kualitatif deskriptif yaitu prosedur penelitian yang menghasilkan data deskriptif berupa kata-kata tertulis atau lisan dari orang-orang dan perilaku yang dapat diamati. Dalam penelitian ini penulis memilih TK Alkhairaat 1 Pusat Palu yang berlokasi di Jalan Mangga No. 2 Kel. Siranindi Kee. Palu Barat, kota Palu Provinsi Sulawesi Tengah.

Teknik pengumpulan data yang digunakan melipuyi teknik observasi, dokumentasi dan wawancara. Adapun teknik analisis data terdiri dari proses reduksi data, penyajian data dan verifikasi data. Pengecekan keabsahan data dalam penelitian ini melalui

${ }^{5}$ Solehudin, Konsep Dasar Pendidikan Prasekolah, (Bandung: Fakultas Ilmu Pendidikan Universitas Pendidikan Indonesia, 2013), 69

${ }^{6}$ Hurlock, Elizabeth B, Perkembangan Anak, (Jakarta: Erlangga, 2002), 180

${ }^{7}$ Hasil survey Sebelum Penelitian dengan Kepala Sekolah dan Beberapa Guru di TK Alkhairaat 1 pusat Palu, tanggal 25 agustus 2018 
diskusi dengan berbagai kalangan yang memahami masalah penelitian ini yaitu dengan sumber-sumber yang sudah memahami dan berpengalaman mengenai meningkatkan kosakata pada anak melalui metode bermain peran

\section{HASIL DAN PEMBAHASAN}

\section{A. Upaya Guru Meningkatkan Kosakata Anak Melalui Metode Bermain Peran di TK Alkhairaat 1 Pusat Palu}

Dalam pengamatan peneliti lakukan adalah adanya upaya guru di TK Alkhairaat 1 pusat Palu khususnya meningkatkan kosakata anak melalui metode bermain peran, guru tidak hanya menyediakan fasilitas ataupun media belajar saja tetapi guru juga harus membimbing peserta didik dan mempunyai strategi dalam menerapkan bermain peran untuk meningkatkan kosakata pada anak.

Untuk mengetahui lebih lanjut bagaimana upaya guru dalam meningkatkan kosakata anak melalui metode bermain peran di TK Alkhairaat 1 pusat Palu, sebagai berikut:

\section{Guru Menyiapkan Rencana Perogram Pembelajaran Harian (RPPH)}

Seorang guru dalam menciptakan suatu sistem lingkungan yang yang baik dalam proses pembelajaran merupakan sesuatu keharusan, agar setiap tujuan pembelajaran yang ingin di capai mampu tercapai secara optimal. Oleh sebab itu seorang guru dituntut untuk menyusun rencana pelaksanaan pembelajran harian. Hasil observasi yang peneliti lakukan dari tanggal 16 Oktober sampai dengan 6 November 2019 bahwasanya sebelum di mulainya pmbelajaran guru sudah terlebih dahulu menyiapkan rencana program pembelajran harian (RPPH) agar dapat tercapainya tujuan pembelajaran, sebagaimana di ungkapkan oleh ibu Masita selaku wali kelas B1:

Sebelum pembelajaran berlangsung guru-guru disini selalu mempersiapkan Rencana Program Pembelajaran Harian (RPPH) terlebih dahulu agar semua kgiatan program semester dapat terlaksana dan pembelajaran bisa berlangsung secara terstuktur dan rapi. Sehinnga tujuanpembelajaran mampu tercapai dengan baik ${ }^{8}$.

Berdasarkan pernyataan diatas maka di TK Alkhairaat 1 pusat Palu selalu menyiapkan RPPH terlebih dahulu dan setelah adanya RPPH guru setiap harinya memberi tahu kepada anak tema apa yang akan diterapkan ketika proses pengajaran contohnya pada tanggal 6 Oktober 2019 diberikan tema Maulid Nabi Muhammas saw dan sub temanya masa nabi Muhammad saw. Sehingga peserta didik bisa melakukan proses kegiatan bermain peran sesuai dengan tema dan anak lebih mengetahui kosakata apa saja yang berkaitan dengan subtema yang diberikan si pendidik.

\section{Guru Memperlihatkan Media Gambar yang Sesuai dengan Tema}

Sebelum masuk di kegiatan bermain peran guru terlebih dahulu memperlihatkan media gambar sambil menuliskan kembali nama gambar dipapan tulis minimal sebanyak

${ }^{8}$ Masita, Wali Kelas B1, “Wawancara” Sekolah TK Alkhairaat 1 Pusat Palu, 16 Oktober 2019 
7 gambar dan guru menjelaskan makna yang terkandung dalam media gambar tersebut agar pengetahuan anak leih berkembang, anak juga harus mengeja kembali huruf kosakata dalam media gambar tersebut, itu salah satu upaya guru untuk memperbanyak kosakata anak, contohnya melatih anak untuk menyebutkan kembali kosakata yang berkaitan dengan subtema.

\section{Guru Membicarakan Alat-Alat yang Akan Digunakan Oleh Peserta DidikUntuk Bermain Peran}

Sebelum di mulainya kegiatan pembelajaran terlebih dahulu guru membicarakan peralatan yang apa saja yang akan di gunakan dalam bermain peran, contonya ketika akan bermain peran temanya tentang makanan kesukaan maka guru terlebih dahulu mempersiapkan berbagai macam alat yang di perlukan misalnya berbagai macam buahbuahan, susu, tusuk sate, daging mainan, piring, gelas, sendok, mangkok dan lain-lain. Sebagai mana yang di kemukan oleh ibu Masita guru kelas B1:

Biasanya ketika akan bermain peran berlangsung saya dan ibu Indri selalu mempersiapkan alat-alat yang akan di butuhkan sebelum permainan di mulai tujuannya agar tidak pembelajaran bisa berjalan dengan baik ${ }^{9}$.

Sebagaimana di ungkapakan pula oleh Ibu Saona S Mahmud selaku kepala sekolah TK Alkhairaat 1 pusat Palu:

Guru disini biasanya selalu menyiapkan media dan alat permaianan dengan baik, karena saya termasuk kepala sekolah yang teliti dan protektif dalam proses belajar mengajar, alat dan bahan biasanya tidak sulit untuk didapat dan masih ada pada lingkungan sekitar ${ }^{10}$.

Dari pernyataaan di atas peneliti menyimpulkan bahwasanya di TK Alkhairaat 1 pusat Palu selalu mempersiapkan terlebih dahulu alat dan bahan sebelum di mulainya pembelajaran tersebut.

\section{Guru Membagikan Tugas Kepada Anak Sebelum Bermain Peran Menurut Kelompoknya Agar Tidak Berebut}

Berdasarkan hasil observasi dilapangan pada saat akan di lakukannya bermain peran, terlebih dahulu guru membagikan tugas kepada anak tujuannya agar anak tidak berebut ketika melakukan bermian peran berlangsung, Anak bermain sesuai tempatnya, anak bisa pindah apabila bosan. Tujuannya agar anak tidak kebingungan terhadap peran yang diperankannya sebagaimana di kemukakan oleh Ibu Masita selaku guru kelas B1:

Sebelum di mulainya bermain peran maka terlebih dahulu kami guru membagikan tugas kepada anak sesuai dengan perannya agar anak tidak kebingungan terhadap apa yang akan di perankannya, contohnya ketika akan

\footnotetext{
${ }^{9}$ Masita, Wali Kelas B1, “Wawancara” Sekolah TK Alkhairaat 1 Pusat Palu, 16 Oktober 2019

${ }^{10}$ Saona S Mahmud, Kepala Sekolah, “wawancara” Sekolah TK Alkhairaat 1Pusat Palu, 16 Oktober 2019
} 
berperan sebagai Profesi dokter, maka kami selalu membagi tugas kepada anak-anak ada yang bertugas sebagai pak dokter, ada yang penjaga obat, dan juga ada yang menjadi pasien, dll ${ }^{11}$.

Dari pernyataan tersebut maka dapat penulis simpulkan bahwa sebelum di lakukannya bermain peran maka guru membagikan tugas kepada anak dengan tujuan agar anak mampu melakukan perannya dengan baik dan tidak berebut saat memainkan perannya.

\section{Guru Mengumpulkan Anak Untuk Diberi Pengarahan, Memberi Aturan Dalam Permainan, Mengabsen Serta Menghitung Jumlah Anak}

Dari hasil observasi yang penulis amati pada tanggal 16 Oktober sampai 06 November 2019 di TK Alkhairaat 1 pusat Palu, sebelum kegiatan maka guru mengumpulkan anak untuk di beri pengarahan dan aturan dalam bermain peran agar bisa berjalan dengan baik dan kondusif, dalam pengarahan tersebuat guru memberi pengarahan kepada anak, contohnya anak berperan sesuai dengan perannya, tidak diperbolehkan untuk berebutan, belajar untuk di siplin. Serta tidak lupa pula guru mengabsen serta menghitung jumlah anak yang masuk hari itu. Sebagaimana di ungkapkan oleh Ibu Masita selaku tenaga pendidik di kelas B1:

Sebelum dimulainya bermain peran saya selalu mengumpukan anak terlebih dahulu untuk memberi arahan dan juga mengabsen anak agardalam pembagian tugas bisa dilakukan dengan mudah dan anak tidakberebut dengan perannya ${ }^{12}$.

Berdasarkan pernyataan diatas maka dapat disimpulkan bahwa di TK Alkhairaat 1 pusat Palu, sebelum melakukan kegiatan bermain peran guru telah mengumpulka anak dan memberi arahan serta mengabsen anak terlebih dahulu sebelum bermain peran dimulai.

\section{Guru Hanya Mengawasi /Mendampingi Anak Dalam Bermain}

Berdasarkan hasil observasi yang penulis lakukan di TK Alkhairaat 1 Pusat Palu, ketika bermain peran berlangsung pendidik hanya mengawasi saja kegiatan yang di lakukan oleh anak. apabila dibutuhkan anak, guru dapat membantu anak yang masih kebingungan dengan peran yang di mainkan, serta melakukan diskusi untuk mengulas kembali nilai-nilai yang terkandung dalam bermain peran untuk di teladani oleh peserta didik. Sebagaimana di ungkapkan oleh Ibu Masita selaku pendidik kelas B1:

Ketika bermain peran berlangsung saya dan ibu Indri hanya mengawasi kegiatan yang di lakukan oleh anak, agar anak lebih leluasa dalam melakukan peran, sehigga dari hal tersebut pula anak dapat mengeksprsikan keinginan nya begitupun dengan tata bahasa nya akan bertambah dan mengetahui berpa anak yang sudah banyak menguasaikosakata. Tetap kami mengawasi dan membatu jika anak anak terlihat kebingungan dengan peran yang

\footnotetext{
${ }^{11}$ Masita, Wali Kelas B1, “Wawancara” Sekolah TK Alkhairaat 1 Pusat Palu, 16 Oktober 2019

12 Masita, Wali Kelas B1, “Wawancara” Sekolah TK Alkhairaat 1 Pusat Palu, 16 Oktober 2019
} 
dimainkannya ${ }^{13}$.

Selanjutnya di tambahkan juag oleh Ibu Indri bahwasanya:

Diahir kegiatan bermain peran kami selalu mendiskusikan apasaja yang telah di perankan oleh anak-anak,tujuan nya untuk mengulas kembali nilai-nilai yang terkandung dalam bermain peran dan sikap apa saja yang patut untuk di teladani ${ }^{14}$.

Dari pernyataan di atas maka dapat penulis simpulkan bahwa di TK Alkhairaat 1 pusat, guru hanya mengawasi dan sedikit memberi bantuan ketika anak mulai kebingungan dengan peran yang dimainkannya tujuannya tidak lain agar anak mampu seoptimal mungkin mengekspresikan perannya, guru di TK Alkhairaat 1 Pusat Palu juga melalukan diskusi untuk mengevaluasi nilai-nilai yang terkandung dalam kegiatan bermain peran tersebut, dengan tujuan agar anak mampu meneladani sikap yang terkandung dalam kegiatan bermain peran tersebut. Dan mengevaluasi pada saat selesai melakukan bermain peran. Maka penulis menghampiri salah seorang anak untuk mengetahui respon dari anak yang bernama Aqila Azkadina, anak tersebut mengatakan bahwa :

Iya saya sangat suka belajar bermain peran penjual obat, apalagi saya kemaren jadi menjadi pembeli yang bisa makan bernbagai macam buah waktu bermain peran pedagang ${ }^{15}$.

Berdasarkan pernyataan di atas maka dapat penulis simpulkan bahwasanyaguru di TK Alkhairaat 1 pusat Palu hanya mengawasi dan sedikit memberi bantuan ketika anak mulai kebingungan dengan peran yang dimainkannya tujuannya tidak lain agar anak mampu seoptimal mungkin mengekspresikan perannya. Lalu guru di TK Alkhairaat 1 pusat Palu juga melalukan diskusi untuk mengevaluasi nilai-nilai yang terkandung dalam kegiatan bermain peran tersebut, dengan tujuan agar anak mampu meneladani sikap yang terkandung dalam kegiatan bermain peran tersebut.

\section{Anak Bermain Peran Sesuai Tempatnya, Anak Bisa Berpindah Apabila Bosan}

Dari hasil observasi yang peneliti amati dilakukannya bermain peran anak bebas memainkan perannya sesuai dengan apa yang dia inginkan, dan anak juga bisa berpindah tempat apabila sudah mulai bosan, maka anak akan bergantian perannya terhadap temannnya. Contonya seperti Alfah ketika ia ditunjuk untuk menjadi seorang dokter namun karena sudah bosan maka bergantian dengan daftan yang tadinya menjadi pasien. dan begitupun dengan anka-nak lainnya. Untuk memperkuat bahwasanya penerapan bermain peran mampu meningkatkan kosakata pada anak usia dini di TK Alkhairaat 1

\footnotetext{
${ }^{13}$ Masita, Wali Kelas B1, “Wawancara” Sekolah TK Alkhairaat 1 Pusat Palu, 16 Oktober 2019

${ }^{14}$ Indri, Wali Kelas B1, "Wawancara” Sekolah TK Alkhairaat 1 Pusat Palu, 16 Oktober 2019

${ }^{15}$ Aqila Azkadina, Peserta Didik B1, "Wawancara” Sekolah TK Alkhairaat 1 Pusat Palu, 16 Oktober 2019
} 
pusat Palu, berikutdapat dilihat dari indikator tingkat pencapaian perkembangan kosakata anak yaitu:

a. Anak bisa menyebukan kembali kosakata yang berkaitan dengan sub tema

Dari hasil observasi hampir semua anak bisa menyebutkan kembali kosakata yang sudah guru sebutkan satu-persatu disaat memperlihatkan media gambar kepada anak. sebagaimana di ungkapkan oleh Ibu Masita selaku tenaga pendidik di kelas B1:

Ketika saya memberikan pertanyaan sesuai dengan media yang di perlihatkan kepada anak mereka sangat antusias untuk menjawab dan menyebutkan kembali satu-peratu kosakata yang sudah saya tulis di papan tulis ${ }^{16}$.

\section{b. Anak mampu menjawab pertanyaan tentang peran yang dimainkannya}

Dari hasil observasi yang penulis lakukan mengenai penerapan metode bermain peran untuk meningkatkan kosakata pada anak usia dini di TK Alkhairaat 1 pusat Palu. Sebagaimana di ungkapkan oleh Ibu Masita selaku tenaga pendidik di kelas B1:

Saat kegiatan bermain peran berlangsung seringkali saya bertanya kepada anak tentang peran yang mereka lakukan dan bisa dilihat leih banyak anak yang sudah bisa menjawab dengan baik sesuai harapan ${ }^{17}$.

Dari pengamatan yang penulis lakukan terdapat 6 orang yang berkembang sangat baik terlihat dari menjawab pertanyaan-pertanyaan yang di ajukan oleh guru mampu di jawab secara kompleks saat bermain peran. 10 Anak berkembang sesuai harapan, sedangkan 4 anak baru mulai berkembang pengucapan kosakatanya.

\section{c. Anak dapat menceritakan kembali kegiatan bermain peran yang dilakukan}

Anak dapat menceritakan kembali kegiatan bermain peran yang dilakukan dan sudah berkembang dengan baik, hal tersebut dapat dilihat pada saat mereka bermain peran, mereka yang biasanya selalu susah untuk di atur dan selalu jalan- jalan dikelas serta tidak biasanya sering bertanya serta gampang sekali jenuh namun setelah dilakukannya bermain peran ini anak- anak justru lebih sering menggunakan komunikasi, lebih banyak bertanya, mempunya pembendraharaan kata yang sudah mulai membaik. Sebagaimana di ungkapkan oleh Ibu Masita selaku tenaga pendidik di kelas B1:

Sebelum waktu jam pulang saya selalu mengevaluasi kembali dan menanyakan langsung tentang kegiatan bermin peran seperti berperan sebagai apa, terus melakukan kegiatan apa berikutnya dan bermain apa saja tadi, saya melihat sudah lebih banyak anak yang langsung menjawab dan mencritakan kembali tentang peran yang dimainkanya ${ }^{18}$.

\footnotetext{
${ }^{16}$ Masita, Wali Kelas B1, “Wawancara” Sekolah TK Alkhairaat 1 Pusat Palu, 16 Oktober 2019

${ }^{17}$ Masita, Wali Kelas B1, “Wawancara” Sekolah TK Alkhairaat 1 Pusat Palu, 16 Oktober 2019

${ }^{18}$ Masita, Wali Kelas B1, “Wawancara” Sekolah TK Alkhairaat 1 Pusat Palu, 16 Oktober 2019
} 
Sebagaimana di ungkapkan pula oleh Ibu Herlina sebagai orangtua anak murid di kelas B1:

Ketika saya bertanya kepada anak saya bermain peran apa saja tadi dikelas, langsung anak saya menceritakan kegiatan saat dia melakukan bermain peran bersama teman-temannya ${ }^{19}$.

Dari pengamatan yang penulis lakukan terdapat 6 orang anak yang berkembang sangat baik terlihat dari anak-anak mampu berceritakan kembali saat setelah selesai bermain peran. 9 Anak berkembang sesuai harapan, sedangkan 5 anak mulai berkembang Dalam hal ini penulis melihat bahwa anak sudah mulai mampu menceritakan kembali kegiatan bermain peran yang dilkukaannya

\section{d. Anak dapat menyampaikan pendapatnya}

Dari hasil observasi yang penulis lakukan pada mengenai upaya guru dalam meningkatkan kosakata anak melalui metode bermain peran di T Alkhairaat 1 pusat Palu. Ketika jam pulag sekolah saya mewawancarai salah seprang orangtua murid tentang apakah anaknya sudah mampu menyampaikan pendapatnya. Sebagaimana di ungkapkan pula oleh Ibu Sakinah sebagai orangtua anak murid di kelas B1:

Ketika saya bertanya kepada anak saya bagaimana perasaanya saat melakukan kegiatan bermain peran, dan kata anak saya dia sangat suka dan senang bermain peran karena bisa bermain masak-masak seperti mamayang selalu memasak didapur ${ }^{20}$.

Dari pengamatan yang penulis lakukan 6 orang yang berkembang sangat baik terlihat dari menyampaikan pendapatnya saat bermain peran. 10 Anak berkembang sesuai harapan, sedangkan 4 anak mulai berkembang.

\section{e. Anak dapat menyampaikan apa yang ada didalam pikirannya}

Hal tersebut dapat terlihat pada saat mereka melaksanakan bermain peran, seperti ketika bermain peran tentang pedagang ada anak mengungkapkan bahwa kemarin ibu aku juga kepasar dan membeli buah apel, Dan masih bnyak yang lainnya. Sebagaimana di ungkapkan oleh Ibu Masita selaku tenaga pendidik di kelas B1:

Ketika saat bermain ada terdapat anak yang menyampaikan yang ada difikiranya seperti saat melakukan bermain peran tentang memasak salva mengungkapkan ibunya dirumah selalu memasak daging didapur ${ }^{21}$.

Dari pengamatan yang penulis lakukan 8 orang yang berkembang sangat baik

${ }^{19}$ Herlina, Orang Tua Murid, "wawancara” Sekolah TK Alkhairaat 1 pusat Palu, 16 Oktober 2019

${ }^{20}$ Sakinah, Orang Tua Murid, "wawancara” Sekolah TK Alkhairaat 1 pusat Palu, 16 Oktober 2019

${ }^{21}$ Masita, Wali Kelas B1, "Wawancara” Sekolah TK Alkhairaat 1 Pusat Palu, 16Oktober 
terlihat dari anak mampu menyampaikan apa yang ada dalam pikirannya saat bermain peran, sedangkan 12 anak mulai berkembang.

\section{f. Anak dapat menyusun kata-kata ketika memainkan perannya}

Dari hasil observasi yang penulis lakukan dari pengamatan tersebut maka peneliti dapat mengamati anak-anak sudah mampu untuk menyusunkata-kaat ketika memaikan perannya. Sebagaimana di ungkapkan oleh Ibu Masita selaku tenaga pendidik di kelas B1:

Ketika bermain peran anak sudah bisa menyusun kata-kata yang mudah seperti sedang memerankan menjadi penjual anak mampu menyebutkan kalimat seperti: mau beli apa, harganya murah, mau pesan berapa ya, dan kalimat-kalimat pendek lainya ${ }^{22}$.

Dari hasil pengamatan tersebut maka ada 6 anak yang sudah berkembnag sangat baik, 3 anak yang berkembang sesuai harapan 11 anak yang sudah mulai berkembang. Dalam hal ini penulis melihat bahwa anak sudah mulai mampumenyusun kalimat sederhana seperti dalam struktur yang lengkap seperti ibu pergi ke pasar

B. Faktor Pendukung Guru Dalam Meningkatkan Kosakata Anak Melalui Metode Bermain Peran di TK Alkhairaat 1 pusat Palu

1. Kemampuan guru dalam menerapkan metode bermain peran Sebagai pendidik bukan hanya menyiapkan media atau ala permainan saat menerapkan metode bermain peran tetapi guru juga harus punya cara untuk menerapkan metode bermain peran dengan semaksimal mungkin yang menjadikan kelas lebih aktif, peserta didik lebih antusias dan tidak mudah bosan saat bermin peran, sebagaimana di kemukakan oleh Ibu Masita selaku guru kelas B1:

Sebagai guru saya selalu menyiapkan strategi sebelum melakukan kegiatan bermain peran sesuai dngan tema yang akan diajarkan kepadapeserta didik, dan harus mngetahui masing-masing sifat dan karakter setiap anak, sehingga guru bisa melihat apa saja yang menjadi kesukaan dan minat peserta didik saat memainkan peran. Dan ketika anak mulai bosan guru membiarkan anak untuk berpindah ketempat kegiatan lainya seperti bermain boneka dan mobilmobilan atau mewarnai gambar dibuku paket ${ }^{23}$.

Berdasarkan pernyataan diatas maka dapat disimpulkan bahwa di TK Alkhairaat 1 pusat Palu, sebelum melakukan kegiatan bermain peran guru sudah mempunyai cara atau strategi untuk menerapkanya kepada peserta didik agarproses kegiatan bermain peran bisa berjalan dengan baik.

2. Sarana dan prasarana

Dari faktor pendukung diantaranya adalah sarana dan prasanan, dari hasil observasi 2019

${ }^{22}$ Masita, Wali Kelas B1, “Wawancara” Sekolah TK Alkhairaat 1 Pusat Palu, 16Oktober

${ }^{23}$ Masita, Wali Kelas B1, “Wawancara” Sekolah TK Alkhairaat 1 Pusat Palu, 16 Oktober 2019 
dan wawancara di TK ALkhairaat 1 Puat Palu tidak hanya memiliki tenaga pendidik yang cerdas, kreativ dan berkualitas tetapi juga dengan adanya sarana dan prasaran yang sangat memadai sehingga mendukung terhadap proses kegiatan belajar atau bermain peserta didik. Sebagaimana di ungkapkan ibu Saona S Mahmud selaku kepala sekolah TK Alkhairaat 1 pusat Palu:

Sebagai kepala sekolah saya sangat memperhatikan dan memantau sarana dan prasarana dari dalam kelas sampai lingkungan sekolah, karena proes pembelajaran peserta didik akan berjalan dengan baik ketika sarana dan prasarananya sngat memadai sehingga peseta didik disini bisa belajar dan bermain dengan nyaman dan bisa berpidah-pindah tempat bermain ketika bosan. Dan tenaga pendidk disini juga diberikan fasilitas agar bisa lebih mendukung saat proes kegiatan pembelajaran berlangsung seperti media pembelajaran dan berbagai alat permainanan ${ }^{24}$.

Sebagaimana dikemukakan pula oleh ibu Masita selaku guru kelas B1:

Saya bersama ibu Indri selalu menyiapkan media dan alat permaianan apa saja yang akan digunakan sebelum prose kegiatan bermain peranberlangsung kami menyiapkanya sesuai dengan tema yang telah ditentukan di RPPH, agar kegiatan bermain peran berjalan dngan lancar dan seuai dngn tujuan pembelajaran $^{25}$.

Dari pernyataaan diatas penulis menyimpulkan bahwa di TK Alkhairaat 1 pusat Palu sudah sangat bagus sarana dan prasarananya sehingga menjadi faktor pendukung dalam guru meningkatkan kosakata anak memalui metode bermain peran.

\section{Faktor Penghambat Guru Dalam Meningkatkan Kosakata Anak Melalui Metode Bermain Peran di TK Alkhairaat 1 pusat Palu}

Dari hasil observasi dan wawancara di TK Alkhairaat 1 pusat Palu dihadapkan dengan adanya faktor penghambat dalam guru meningkatkan koskata anak melalui metode bermain peran. Sebagaimana diungkapkan oleh ibu Masita selaku guru kelas B1:

Menurut saya faktor penghambat dalam menerapkan metode bermain peran itu tidak ada, karena dari mulai sarana dan prasarana, tempat bermain dan fasilitas yang digunakan sudanh sangat cukup baik dan memadai, hanya saja faktor penghambat dalam upaya guru meningkatkan kosa kata anak terdapat di peserta didik yang jarang hadir di sekolahsehingga peserta didik tidak mengikuti atau ketinggalam dalam melaukan kegiatan bermain peran sesuai tema yang sudah ditentukan dalam RPPH. Dan membuat peserta didik terhambat dalam penguasan kosakata sehinggamasih ada anak yang tidak sama pengucapan kosa katanya dengan anak lainnya ${ }^{26}$. Oktober 2019

${ }^{24}$ Saona S Mahmud, Kepala Sekolah, “wawancara” Sekolah TK Alkhairaat 1Pusat Palu, 16

25 Masita, Wali Kelas B1, “Wawancara” Sekolah TK Alkhairaat 1 Pusat Palu, 16 Oktober 2019

${ }^{26}$ Masita, Wali Kelas B1, “Wawancara” Sekolah TK Alkhairaat 1 Pusat Palu, 16 Oktober 2019 
Berdasarkan pernyataan di atas maka dapat disimpulkan bahwa di TK Alkhairaat 1 pusat Palu, dalam menerapakan metode bermain peran tidak terdapat faktor penghambat untuk guru, hanya ada faktor penghambat yang berasal dari beberapa anak yang jarang hadir disekolah sehingga anak tersebut ketinggalan untuk mengikuti kegiatan bermain peran bersama teman-teman sekelasnya dan berpengaruh kepada peningatan kosakata anak yang belum lancar.

\section{KESIMPULAN}

Berdasarkan hasil dan pembahasan yang telah dijelaskan maka penulis dapat mengemukakan beberapa kesimpulan yakni:

1. Upaya guru dalam meningkatkan kosakata anak melalui bermain metodebermain peran yaitu:

a. Guru menyiapkan rencana program pembelajaran harian (RPPH)

b. Guru memperlihatkan media gambar yang sesuai dengan tema

c. Guru membicarakan alat-alat yang akan digunakan oleh anak untukbermain peran

d. Guru membagi tugas kepada anak sebelum bermain peran menurut kelompoknya agar tidak berebut

e. Guru mengumpulkan anak untuk diberi pengarahan, memberi aturandalam permainan, mengabsen serta menghitung jumlah anak

f. Guru hanya mengawasi/mendampingi anak dalam bermain

g. Anak bermain peran sesuai tempatnya, anak bisa berpindah apabilabosan

2. Faktor pendukung dan penghambat guru dalam meningkatakan kosakata anak melalui metode bermain peran di TK Alkhairaat 1 Pusat Palu yaitu:

a. Kemampuan guru dalam menerapkan metode bermain peran Sebagai pendidik bukan hanya menyiapkan media atau alat permainan saat menerapkan metode bermain peran tetapi guru juga harus punya cara untuk menerapkan metode bermain peran dengan semaksimal mungkin yang menjadikan kelas lebih aktif.

b. Sarana dan prasarana. Dari hasil observasi dan wawancara di TK ALkhairaat 1 Puat Palu tidak hanya memiliki tenaga pendidik yang cerdas, kreatif dan berkualitas tetapi juga dengan adanya sarana dan prasaran yang sangat memadai sehingga mendukung terhadap proses kegiatan belajar atau bermain peserta didik.

3. Faktor penghambat guru dalam meningkatakan kosakataanak melalui metode bermain peran di TK Alkhairaat 1 Pusat Palu yaitu:

Berdasarkan hasil observasi dapat disimplkan, bahwa merepakan metode bermain peran tidak terdapat faktor pengambat untuk guru. Hanya ada faktor penghambat yang berasal dari beberapa anak yang jarang hadir disekolah sehingga anak teraebut ketinggalan untuk mengikuti kegiatan bermain peran bersama teman- 
teman sekelasnya dan membuat anak masih belum banyak menguasai kosakata dengan lancer

\section{SARAN}

Sebagai tindak lanju penelitian yang penulis lakukan maka ada beberapa saran sebagai berikut:

1. Bagi kepala sekolah diharapkan lebih memperhatikan lagi kualitas sarana dan prasarana sekolah baik media maupun alat permainan edukatif yang ada di kelas, khususnya alat-alat permainan dalam kegiatan bermain peran agar para pesrta didik semakin bersemangat dalam mengikuti kegiatan pembelajaran.

2. Bagi guru, perlu kiranya guru lebih bervariatif dalam memberikan kegiatan pembelajaran, dan lebih meningkatkan cara atau strategi khususnya dalam melakukan kegiatan bermain peran untuk meningkatkan kosakata anak, sehingga anak dapat lebih antusias dan lebih tertarik dalam mengikuti kegiatan pembelajaran. Motivasi dan bimbingan perlu lebih ditingkatkan oleh guru agar dapat memacu semangat belajar anak dan anak semakin rajin ke sekolah.

\section{DAFTAR PUSTAKA}

Arikunto Suharsimi, Dasar-Dasar Evaluasi Pendidikan. Jakarta: Bumi Aksara, 2013.

Christiana Hari Soetjiningsih, Seri psikologi perkembangan anak sejak pembuahan sampai dengan kanak-kanak ahir. Depok: Prenada Media Group, 2018.

Gunarti, Winda, dkk. Metode Pengembangan Perilaku dan Kemampuan Dasar Anak Usia Dini. Jakarta: Universitas Terbuka, 2008.

Hurlock, E. B. Psikologi Perkembangan 5th edition. Jakarta: Erlangga, 2002

Solehudin, Konsep Dasar Pendidikan Prasekolah, Bandung: Fakultas Ilmu Pendidikan Universitas Pendidikan Indonesia, 2013

Wiyani, Andy Novan, Psiklogi Perkembangan Anak Usia Dini Panduan Bagi Oragtu dan Pendidik Dalam Memahami Serta Mendidik Anak Usia Dini, Yogyakarta: Penerbit Gava Media, 2014. 